\title{
Potential of Red Sandalwood (Adenanthera pavonina L.) as an Antibacte- rial Agent against Clinical Isolates
}

\author{
Tanveer Abbas ${ }^{1, *}$, Faryal Liaquat ${ }^{1}$, Saira Yahya ${ }^{2}$ Farhana Tasleem ${ }^{3}$, Iqbal Azhar ${ }^{3}$ and Zafar Alam \\ Mehmood $^{4}$
}

\author{
${ }^{I}$ FSRG, Department of Microbiology, University of Karachi, 75270, Karachi, Pakistan. \\ ${ }^{2}$ Department Of Microbiology, University Of Karachi, Pakistan. \\ ${ }^{3}$ Department of Pharmacognosy, Faculty of Pharmacy, University of Karachi, Pakistan. \\ ${ }^{4}$ Colorcon Limited, Crossways, Victoryway, Kent, Dartford, England.
}

\begin{abstract}
The emergence of resistant pathogens is a leading cause of morbidity worldwide. For the treatment of diseases caused by these resistant pathogens, the use of medicinal plants as an alternative to synthetic drugs is increasing. Therefore, the aim of this study was to evaluate the efficacy of hexane and ethanolic extracts of a natural plant Adenanthera pavonina L. Antibacterial activity of Adenanthera pavonina $L$. leave extracts and pure compound ( $\beta$-sitosterol glucoside) against Enterrococcus spp., S. aureus, P. aeruginosa, S. typhi, E. coli, Proteus spp., K. pneumonia and A. baumanii, was carried out by well-diffusion assay and micro-dilution technique. Moreover, time-kill tests were carried out to assess the antimicrobial activity of the Adenanthera pavonina L. extracts against $E$. coli. The results showed good antibacterial potential of Adenanthera pavonina L. extracts against the clinical isolates tested.
\end{abstract}

Keywords: Antibacterial potential, $\beta$-sitosterol glucoside, Adenanthera pavonina $L$.

doi.org/10.21089/njhs.22.0061

\section{INTRODUCTION}

Antibiotics, which are either derived from microorganisms or synthesized chemically, provide the base of clinical therapy. Every year, two to three antibiotics were sprung into the global market, but due to the emergence of multi-drug resistant microbial strains, scientist are looking forward for the development of alternative and novel drugs [1]. Natural sources such as plants, offer a wide variety of natural medicinal compounds for therapeutic treatments $[1,2]$. Their use for the treatment of diseases is increasing day by day because of their added advantages such as low toxicity, good therapeutic performance, cost-effectiveness and ecofriendliness [3-6]. In order to understand the antimicrobial efficacy of these medicinal plants, their properties should be thoroughly investigated.

The most common plants used for therapeutic purposes worldwide are Lannea kerstingii, Curcuma xanthorrhiza, Senna alata, Moringa oleifera, Adenanthera pavonina $L$. and Pangium edule. The plant Adenanthera pavonina L., native to the subcontinent was chosen in this study. Adenanthera

\footnotetext{
*Address correspondence to this author at the Department of Microbiology, University of Karachi, 75270, Karachi, Pakistan.

E-mail: taabbas@uok.edu.pk
}

pavonina $L$. is also known as Red Bead Tree (Red sandal wood) and belongs to the family Fabaceae [7]. Various parts of this plant have been traditionally used for treating diarrhea, gout and inflammations [8]. Its bark is typically used for the treatment of gonorrhea, haematuria, ulcers and it is also used as an ointment [9-16].

Several documented phytochemical studies on this plant revealed the presence of secondary metabolites, mainly flavonoids, triterpenoids, tannins, saponins and sterols $[5,10,11]$. The chief constituents are flavonoid compounds $[12,13]$. It is used as an aseptic paste and also used to treat boils and inflammation [12, 14]. Its wood is red in color and extremely hard wood timber is used for building purposes and furniture making [12]. It is also able to fix nitrogen [5, 15].

Plants generally synthesize ethyl sterols (sitosterols) while fungi, algae and protozoa, synthesize methyl sterols (ergosterols) [17]. Among the phytosterols, predominant is $\beta$-sitosterol which are structurally similar to cholesterol. $\beta$ sitosterols are present in natural foods and are considered as the health promoting constituents. They also possess pharmacological activities such as anti-inflammatory activity, immunomodulatory activity, chemoprotective effects, inducing apoptosis and angiogenic effect [18]. 
Owing to the therapeutic properties of Adenanthera pavonina $L$., this study was carried out to evaluate the antibacterial potential of leave extracts and a pure compound- $\beta$ sitosterol glucoside, isolated from Adenanthera pavonina $L$.

\section{MATERIALS AND METHODS}

\section{Microbial Strains}

Total 8 clinical isolates were used in this study which were provided by a clinical laboratory. Out of these 8 isolates, two were Gram-positive (Enterrococcus spp., S. aureus) and six were Gram-negative ( $P$. aeruginosa, S. typhi, E. coli, Proteus spp., K. pneumonia and A. baumanii).

\section{Preparation of 0.5 McFarland}

McFarland standards are used as a reference to adjust the turbidity of bacterial suspensions. It was prepared by mixing $0.05 \mathrm{ml}$ of $1 \% \mathrm{BaCl}_{2 \cdot 2} \mathrm{H}_{2} \mathrm{O}$ with $9.95 \mathrm{ml}$ of $1 \% \mathrm{H}_{2} \mathrm{SO}_{4} \cdot \mathrm{A}_{600}$ was taken by using a spectrophotometer and stored in a refrigerator until use [19].

\section{Preparation of Inoculum}

Pure microbial isolates were streaked onto nutrient agar medium. Subsequently, isolated colonies were transferred in sterile PBS and turbidity of the suspension was adjusted to $0.5 \mathrm{McFarland}$ standard [20].

\section{Preparation of Extracts}

Leaves of Adenanthera pavonina L. were soaked in hexane and ethanol for fifteen days, filtered and filtrate was evaporated under reduced pressure by means of rotary evaporator, while the pure compound was isolated from the leaves of Adenanthera pavonina L. [21].

\section{Determination of Antimicrobial Potential}

The antimicrobial activity of the extracts and pure compound i.e. $\beta$-sitosterol glucoside was evaluated against the clinical isolates. The procedures, well-diffusion assay and minimal inhibitory concentration (MIC) were carried out as per Clinical Laboratories Standards Institute (CLSI) guidelines to check the antibacterial sensitivity $[20,21]$. Time-kill assay of the extracts and compounds against $E$. coli was also investigated. Berberis vulgaris extract was used as a positive control throughout the study.

\section{Well-Diffusion Assay}

Sensitivity test was performed using agar well-diffusion method. A lawn of bacterial inoculum (matched with 0.5 McFarland turbidity standard) was made on Mueller-Hinton agar plate. The plant extract or $\beta$ - sitosterol glucoside (100 $\mu \mathrm{l}$ ) was added in a $7 \mathrm{~mm}$ well punched aseptically in the agar plate with a sterile cork borer and was incubated at $37^{\circ} \mathrm{C}$ for
$24 \mathrm{~h}$. The sensitivity was determined based on the diameter of the zone of inhibition around the well [20-24].

\section{Minimum Inhibitory Concentration (MIC)}

The sensitivity of microbes to ethanolic extract was measured by micro dilution method using 96-well microtiter plate. The extract was serially diluted (two-fold) in MuellerHinton broth, $10 \mu \mathrm{l}$ culture was added in each well along with the positive and negative controls and the plates were incubated at $37^{\circ} \mathrm{C}$ for $24 \mathrm{~h}$. $\mathrm{A}_{540}$ was read by ELISA plate reader (Tecan sunrise, Switzerland). MIC's were calculated in percentages and in $\mathrm{mg} / \mathrm{ml}$.

\section{Time-Kill Assay}

To determine at which time of bacterial growth the test compound exerted its killing effect, a time kill assay was carried out. The experiment was performed by inoculating test organism (E. coli) in Nutrient broth and incubating at $37^{\circ} \mathrm{C}$ for $24 \mathrm{~h}$. It was matched with $0.5 \mathrm{McFarland}$ and broth culture was diluted to $10^{-3}$ dilution. $1 \mathrm{ml}$ of culture was added with $0.1 \mathrm{ml}$ of extract in dry cuvettes. $\mathrm{A}_{600}$ was measured after different time interval at $0 \mathrm{~min}, 30 \mathrm{~min}, 60 \mathrm{~min}, 120 \mathrm{~min}$, $240 \mathrm{~min}$ and $1440 \mathrm{~min}$.

\section{Statistical Analysis}

Data was organized and tabulated using Microsoft word and Excel 2007. Pearson's correlation was calculated for all three extracts vs. natural antimicrobial agent Berberis vulgaris. Time-kill assay graphs were made by using online DMFit, web edition (Dynamic modeling fit).

\section{RESULTS AND DISCUSSIONS}

Many infectious diseases have been known from history to be treated with herbal remedies due to their antibacterial activity against a large number of microbes as well as their reasonable cost [25-29]. The activity of plant extracts against bacteria is due to the presence of phytoconstituents, which may vary due to certain factors such as locality of plant growth, harvesting and extraction methods.

In this study two methods were used to determine the efficacy of Adenanthera pavonina L. against the bacterial strains i.e. the well-diffusion method and the microdilution method (Minimum Inhibitory Concentration).

\section{Antibacterial Activity Determination by Well-Diffusion Assay}

The results indicate that the Adenanthera pavonina L. leave extracts showed antibacterial activity against the respective clinical isolates with different diameter of zone of inhibition and only Proteus spp. showed resistance to all extracts (Table 1). The ethanolic extract was effective against Enterococcus spp., E. coli, S. aureus and A. baumannii with zone of inhibitions of $7 \mathrm{~mm}, 17.5 \mathrm{~mm}, 8 \mathrm{~mm}$ and $17 \mathrm{~mm}$ respective- 
ly. S. aureus, P. aeruginosa and S. typhi showed sensitivity with zones of inhibition of $10 \mathrm{~mm}$ and Enterococcus spp. with $11 \mathrm{~mm}$ diameter to hexane extract of Adenanthera pavonina $L$. Similar results have been reported by several workers [30, 31].

The antibacterial activity showed by Adenanthera pavonina $L$. pure compound ( $\beta$-sitosterol glucoside) to $S$. aureus, E. coli and A. baumanii measured in diameter was $15 \mathrm{~mm}, 9$ $\mathrm{mm}$ and $11 \mathrm{~mm}$ respectively. The potential of $\beta$-sitosterol as an antibacterial agent from Senecio lyratus is documented by Kiprono et al. in 2000 [32]. In a study by Sen et al. (2012), the antimicrobial activity of pure $\beta$-sitosterol is reported ranging from 10 to $14 \mathrm{~mm}$ for $P$. aeruginosa, E. coli, $K$. pneumonia, and $S$. aureus which is nearly equal to the standard Gentamicin by well-diffusion method.

Table 1. Zone of inhibition. (-) indicates no inhibition Berberis vulgaris as a positive control, correlations were significant for hexane $(\mathrm{r}=$ $\left.0.808, r^{2}=0.654\right)$ and pure compound $(\beta$-sitosterol glucoside $)\left(r=0.252, r^{2}=0.0063\right)$ and insignificant for ethanolic extract $\left(r=-0.084, r^{2}=\right.$ $0.0071)$.

\begin{tabular}{|l|c|c|c|c|}
\hline \multicolumn{1}{|c|}{ Clinical Isolates } & $\begin{array}{c}\text { Pure Compound } \\
(\mathbf{m m})\end{array}$ & $\begin{array}{c}\text { Ethanolic Extract } \\
(\mathbf{m m})\end{array}$ & $\begin{array}{c}\text { Hexane Extract } \\
(\mathbf{m m})\end{array}$ & $\begin{array}{c}\text { Berberis Vulgaris (Positive Control) } \\
(\mathbf{m m})\end{array}$ \\
\hline S. aureus & 15 & 8 & 10.5 & 11 \\
\hline Enterococcus & - & 7 & 11 & 19 \\
\hline P. aeruginosa & - & - & - & 15 \\
\hline E. coli & 9 & 17.5 & 10 & 15 \\
\hline S. typhi & - & - & - & 10 \\
\hline A. baumanii & 11 & 17 & - & 11 \\
\hline K. pneumonae & - & - & - & 11 \\
\hline Proteus spp & - & - & & 15 \\
\hline
\end{tabular}

Table 2. Minimum Inhibitory Concentration presented in percentages and in $\mathrm{mg} / \mathrm{ml}$, significant correlation for hexane $(\mathrm{r}=0.0922$, $\left.r^{2}=0.0085\right)$ and pure compound $\left(r=0.0315, r^{2}=0.001\right) v s$. positive control (Berberis vulgaris) while insignificant for ethanolic extract $\left(\mathrm{r}=-0.674, \mathrm{r}^{2}=0.4553\right)$.

\begin{tabular}{|l|c|c|c|c|}
\hline \multicolumn{1}{|c|}{ Clinical Isolates } & $\begin{array}{c}\text { Ethanolic } \\
\text { Extract }\end{array}$ & $\begin{array}{c}\text { Hexane Extract } \\
(\mathbf{m g} / \mathbf{m l})\end{array}$ & $\begin{array}{c}\text { Pure Compound } \\
(\mathbf{m g} / \mathbf{m l})\end{array}$ & Berberis Vulgaris (Positive Control) \\
\hline S. aureus & $5 \%$ & 25 & 25 & $25 \%$ \\
\hline P. aeruginosa & $10 \%$ & 12.5 & 50 & $6.25 \%$ \\
\hline S. typhi & $10 \%$ & 25 & 25 & $3.1 \%$ \\
\hline E. coli & $10 \%$ & 25 & 25 & $6.25 \%$ \\
\hline Enterococcus & $10 \%$ & 25 & 25 & $12.5 \%$ \\
\hline Proteus & $0.625 \%$ & 25 & 25 & $1.5 \%$ \\
\hline K. pneumoniae & $10 \%$ & 25 & 12.5 & $3.1 \%$ \\
\hline A. baumanii & $10 \%$ & 25 & & \\
\hline
\end{tabular}




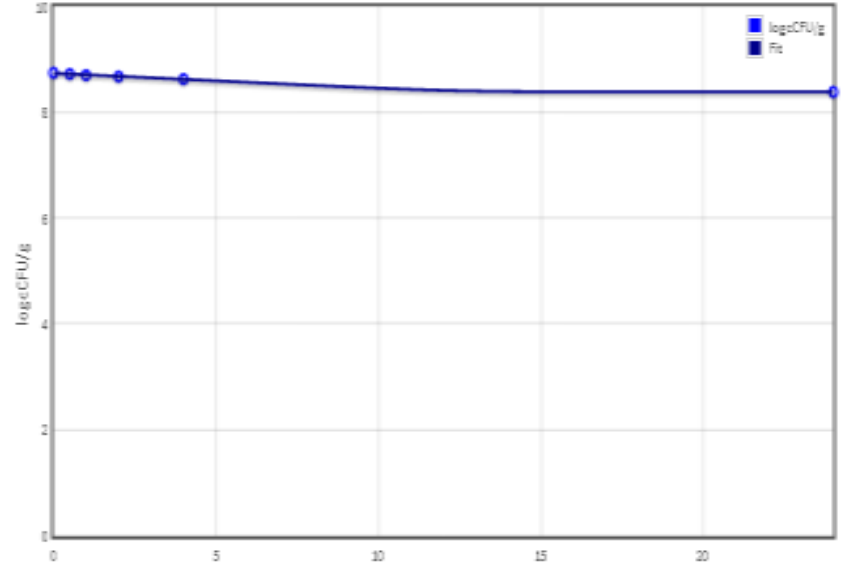

Fig. (1).Time kill of Berberis vulgaris positive control fitted in DmFit (Dynamic modeling fit) $\mathrm{r}^{2}=0.997$ and SE of fit 0.00748 .

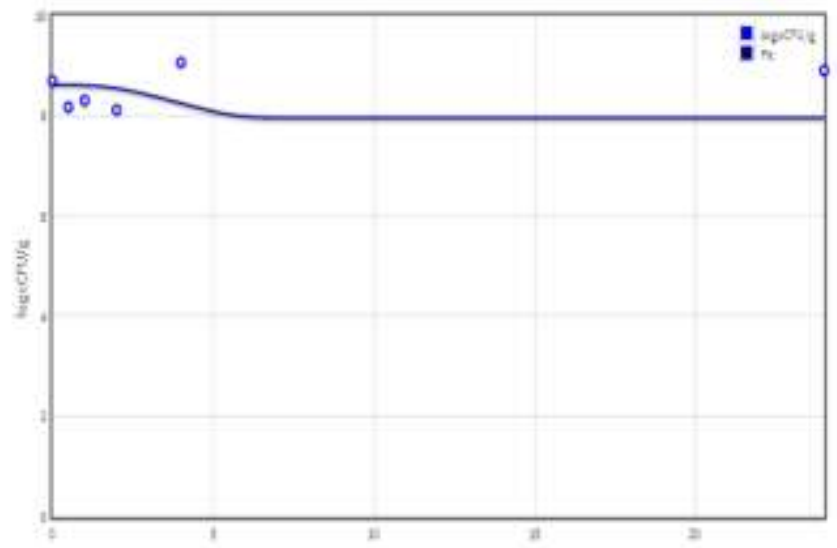

Fig. (2).Time kill of hexane extract of Adenanthera pavonina fitted in DmFit (Dynamic modeling fit) $\mathrm{r}^{2}=0.947$ and SE of fit 0.0638 .

\section{Antibacterial Activity Determination by Minimum inhib- itory Concentration (MIC)}

In clinical laboratories, the micro-dilution method is used routinely as a quantitative reference method therefore it was used in this study. The minimum inhibitory concentration calculated for Adenanthera pavonina $L$. pure compound ( $\beta$ sitosterol glucoside) was $12.5 \mathrm{mg} / \mathrm{ml}$ to $50 \mathrm{mg} / \mathrm{ml}$ (Fig. 2), whereas the MIC of the hexane and ethanolic extracts ranged from $12.5 \mathrm{mg} / \mathrm{ml}$ to $25 \mathrm{mg} / \mathrm{ml}$ and $0.625 \%$ to $10 \%$ respectively. Some clinical isolates failed to show results in welldiffusion assay while minimum inhibitory concentration was determined against them which might be due to reasons like; heavy bacterial growth, large inoculum size or the insolubility of extracts in agar.

\section{Time-Kill Assay}

Time-kill assay of hexane and ethanolic extracts as well as of $\beta$-sitosterol glucosidase was calculated against $E$. coli. The results were compared with the positive control Berberis vulgaris (Fig. 1). Time kill of hexane extract of Adenanthera pavonina $L$. showed the bactericidal activity till two hours after which the extract lost its activity (Fig. 2). Ethanolic extract showed decrease in bacterial count till one hour and stationary phase was observed after that as shown in (Fig. 3). The pure compound $\beta$-sitosterol glucoside also exerted its killing effect and a decrease in bacterial count was observed as shown in (Fig. 4). The results demonstrated that the test compounds exerted their killing effect by acting on the growing cells.

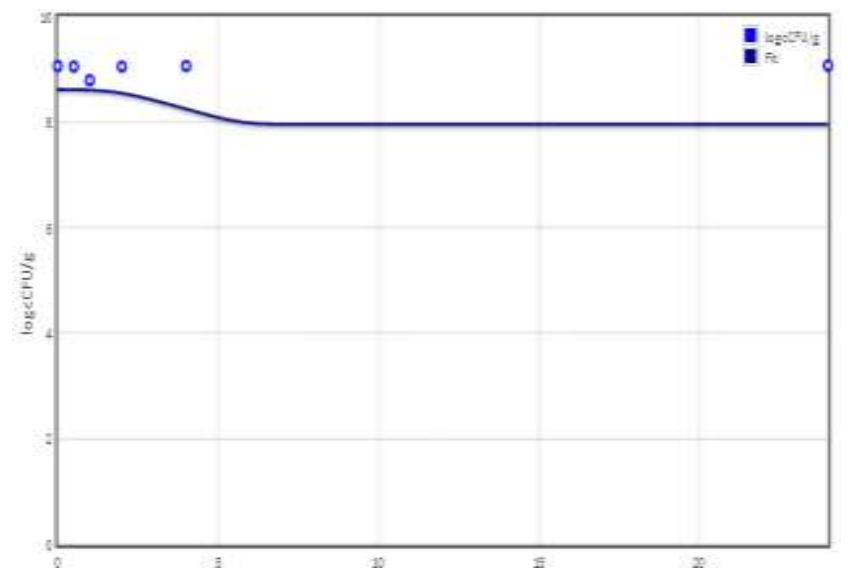

Fig. (3).Time kill of ethanolic extract of Adenanthera pavonina fitted in DmFit (Dynamic modeling fit) $r^{2}=0.947$ and SE of fit 0.0638 .

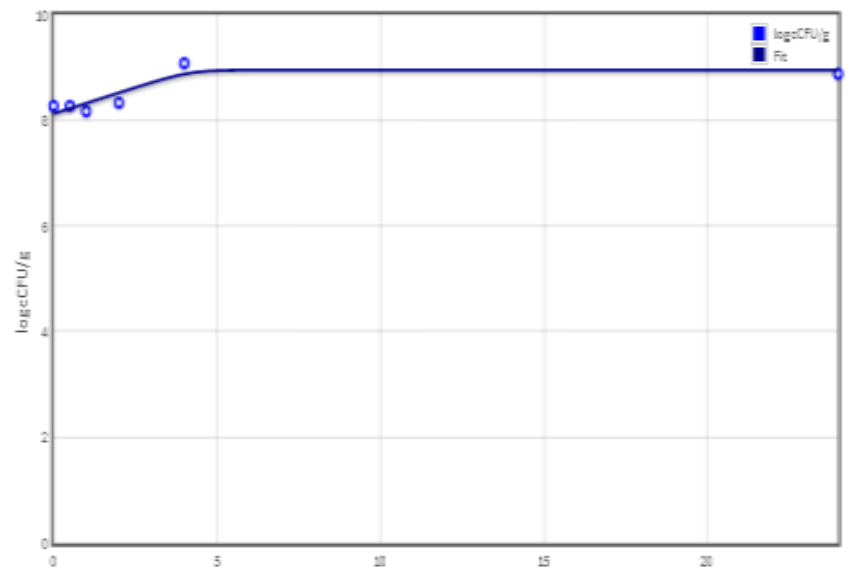

Fig. (4). Time kill of pure compound $\beta$-sitosterol glucoside of Adenanthera pavonina L. fitted in DmFit (Dynamic modeling fit) $\mathrm{r}^{2}$ $=0.701$ and SE of fit 0.208.

\section{CONCLUSION}

This study demonstrated that Adenanthera pavonina $L$. extracts or their bioactive components, if found non-toxic in animal studies and clinical trials, can be effectively used against the most common bacterial infections. 


\section{CONFLICT OF INTEREST}

Declared none.

\section{ACKNOWLEDGEMENT}

The authors are thankful to Dean Faculty of Science, University of Karachi, Karachi. 75270, Pakistan, for providing the financial support for the research.

\section{REFERENCES}

[1] Jayamani E, Rajamuthiah R, Larkins-Ford J, Fuchs B, Conery A, Vilcinskas A, et al. Insect-derived cecropins display activity against acinetobacterbaumannii in a whole-Animal high-throughput caenorhabditiselegans model. Antimicrob. Agents Chemother., 2015; 59(3): 1728-1737. DOI: 10.1128/aac.04198-14

[2] Ocheng F, Bwanga F, Joloba M, Borg-Karlson K, Gustafsson A, Obua C. Antibacterial activities of extracts from Ugandan medicinal plants used for oral care. J. Ethnopharmacol., 2014; 155(1): 852-855. DOI: 10.1016/j.jep.2014.06.027

[3] Yakubu T., SunmonuO, Lewu B, Ashafa O, Olorunniji J, EddouksM. Efficacy and safety of medicinal plants used in the management of diabetes mellitus. J. Evid. Based Complementary Altern. Med., 2014; 1-2. DOI: 10.1155/2014/793035

[4] Vargas N, Ceolin, T, Souza A, Costa M, Ceolin S, Heck R. Medicinal plants used in the process of wound healing by growers in the south region of the RS state. R. Pesq. Cuid. Fundam. Online. 2014; 6(2); 550-560. DOI: 10.9789/2175-5361.2014v6n2p550

[5] Pagano MC, Dhar PP. Fungal pigments: an overview. Fungal biomolecules: sources, applications and recent developments. USA: Wiley-Blackwell; 2015. 173. DOI: 10.1002/9781118958308

[6] Friendly E, Ideas B. Eco friendly business info. Solar Energy. 2014.

[7] Watal G, Dhar P, Srivastava S, Sharma B. Herbal medicine as an alternative medicine for treating diabetes: The global burden. evid. based complement. Alternat. Med., 2014: 1-2. DOI: $10.1155 / 2014 / 596071$

[8] Tiwari R, Chakrabort S, Saminathan M, Kumar A, Karthik K, Wani $\mathrm{M}$, et al. Evidence based antibacterial potentials of medicinal plants and herbs countering bacterial pathogens especially in the era of emerging drug resistance: an integrated update. Int. J. Pharmacol., 2014; 10(1): 1-43. DOI: 10.3923/ijp.2014.1.43

[9] Jawallapersand P, Mashele SS, Kovačič L, Stojan J, Komel R, Pakala SB, et al. Cytochrome P450 monooxygenase CYP53 family in fungi: comparative structural and evolutionary analysis and its role as a common alternative anti-fungal drug target. Plo. S. one. 2014; 9(9): e107209. DOI: 10.1371/journal.pone.0107209.

[10] Tan R., Saga seed tree. 2017. Retrieved from: http://www.naturia.per.sg/buloh/plants/saga_tree.htm

[11] Adedapo AD, Osude YO, Adedapo AA, Moody JO, Adeagbo AS, Olajide AO, et al. Blood pressure lowering effect of Adenanthera pavonina seed extract on normotensive rats. Net. Prod. Res., 2009; 3(2): 82-9.

[12] Adedapo A, Olayinka J, Abiodun O, Oyagbemi A, Azeez O, Adedapo A, et al. Evaluation of antimalarial and antioxidant activities of the methanol seed extract of Adenanthera pavonina (Linn) in Plasmodium berghei infected mice. Asian J. Med. Sci., 2014; 5(4).

[13] Sumathy R, Vijayalakshmi. M, Deecaraman. M, Sankaranarayanan S, Bama P, Ramachandran J. Screening of secondary metabolites, antioxidant and antimicrobial activity from the petals of moringaoleifera. World J. Pharm. Sci., 2014; 3(6): 1829-1843.

[14] Saxena, H, Soni, A, Mohammad N, Choubey S. Phytochemical screening and elemental analysis in different plant parts of Uraria picta Desv.: A Dashmul species. J. Chem. Pharm. Res., 2014; 6(5), 756-760.

[15] Mukda S, Subhadhirasakul S. Herbal medicines and hemorrhoid disease. J. Thai Traditional Alternative Med., 2014; 12(2): 122-132.

[16] Mohammed S., Abou Zeid H, El-Kashoury A, Sleem A, Waly A. A new flavonol glycoside and biological activities of Adenantherapavonina L. leaves. Nat. Prod. Res, 2014; 28(5): 282-289. DOI: $0.1080 / 14786419.2013 .856903$

[17] Silva IK, Soysa P. Evaluation of phytochemical composition and antioxidant capacity of a decoction containing Adenanthera pavonina L. and Thespesiapopulnea L. Pharmacogn. Mag., 2011; 7(27): 193-199.

[18] Richard Van C, Winrock international NFT highlights. A quick guide to useful nitrogen fixing trees from around the world: detailed fact sheet on habit, habitat, distribution, uses. 1993, NFTA 96-01.

[19] Vasavi HS, Arun AB, Rekha PD. Anti-quorum sensing potential of Adenanthera pavonina. Pharmacognosy Res., 2015; 7(1): 105-109.

[20] Performance standards for antimicrobial disk and dilution susceptibility tests for bacteria isolated from animals; approved standard- $3^{\text {rd }}$ edition CLSI Document M31-A3; 2008; 28: 65.

[21] Jorgensen JH, Hindler JA, Barnar K, Citron DM, Cockerinn FR, Fritsche TR, et al. Methods for antimicrobial dilution and disk susceptibility testing of infrequently isolated or fastidious bacteria. Clinical and laboratory standards institute. Approved guideline- $2^{\text {nd }}$ edition, CLSI Document M45-A2, 2010; 30: 18

[22] Shrafee T, Rahman M, Chakraborty A, Prodhan H. Antibacterial potentiality of red sandalwood callus against pathogenic isolates of aeromonas and pseudomonas. Universal J. Plant Science. 2014; 2(4): 86-91. DOI: 10.13189/ujps.2014.020402

[23] Shigemura K, Takase R, Osawa K, Takaba K, Nomi M, Fujisawa M,ArakawaS. Emergence and prevention measures for multidrug resistant Pseudomonas aeruginosa in catheter-associated urinary tract infection in spinal cord injury patients. Spinal Cord. 2015; 53(1): 70-74. DOI: $10.1038 / \mathrm{sc} .2014 .154$

[24] Aghamohammadi M, Faraji M, Shahdousti P, Kalhor H, Saleh A Trace determination of lead, chromium and cadmium in herbal medicines using utrasound assisted emulsification micro-extraction combined with graphite furnace atomic absorption spectrometry. Phytochem. Anal., 2015; 26(3): 209-214. DOI: 10.1002/pca.2554

[25] Shalaby S, Ismail M, Mansour N, Abbas H, Gupta N. Patterns of herbal use among patients attending family practice centers. $E l$. Med. J., 2015; 2(4): 366. DOI: 10.18035/emj.v2i4.348

[26] Laslett L, Jin X, Jones G. Efficacy and safety of plant-derived products for the treatment of osteoarthritis. Botanics. 2015; 5(5): 120. DOI: https://doi.org/10.2147/BTAT.S33431

[27] Murthy N, Georgiev I, Park Y, Dandin S, Paek Y. The safety assessment of food ingredients derived from plant cell, tissue and organ cultures: a review. Food Chem., 2015; 176: 426-432. DOI: 10.1016/j.foodchem.2014.12.075

[28] Adnan M., Bibi R, Mussarat S., Tariq A, Shinwari ZK. Ethnomedicinal and phytochemical review of Pakistani medicinal plants used as antibacterial agents against E. coli. Ann. Clin. Microb. Anti. J., 2014; 13(1): 40. DOI: 10.1186/s12941-014-0040-6

[29] Nwankwo IU, Ukaegbu-Obi KM, Mushtaq A, Pervez S, Hussain S Asif $\mathrm{M}$, et al. Preliminary phytochemical screening and antibacterial activity of two Nigerian medicinal plants (Ficus 
asperifolia and Terminalis catappa), J. Med. Plant Herb. Ther. Res., 2014.

[30] Chemat F. Vian MA, Cravotto G. Green extraction of natural products: concept and principles. Int. J. Mol. Sci., 2012; 13(7): 8615-8627. DOI: 10.3390/ijms13078615
[31] Sen A, Dhavan P, Kshitiz K, Singh S, Tejovathi G. Analysis of IR, NMR and antimicrobial activity of $\beta$-Sitosterol isolated from Momordica charantia. Sci. Secure. J. Biotech., 2012; 1(1): 9-13.

(C) 2017 National journal of health sciences.

This is an open-access article. 